\section{International Scientific Journal Theoretical \& Applied Science}

\author{
p-ISSN: 2308-4944 (print) e-ISSN: 2409-0085 (online) \\ Year: 2015 Issue: 07 Volume: 27 \\ Published: $30.07 .2015 \quad$ http://T-Science.org
}

Igor Viktorovich Balynin postgraduate student, the Department "State and municipal Finance" Financial University under the Government of the

Russian Federation, Russia igorbalynin@mail.ru

SECTION 32. Jurisprudence.

\title{
LEGAL REGULATION OF INSURANCE ACTIVITY IN THE RUSSIAN FEDERATION AND ABROAD
}

Abstract: The article presents the results of the analysis of legal regulation of insurance activity in the Russian Federation (with regard to the existing federal laws, decrees and orders of the government, ministries and PPA Bank of Russia, and others.), As well as insurance law abroad (Bulgaria, France, Germany, Japan, USA and others.) including in a historical context.

Key words: insurance, insurance code, the codification of the insurance legislation, codification, insurance law, civil liability insurance, insurance coverage, international experience.

Language: Russian

Citation: Balynin IV (2015) LEGAL REGULATION OF INSURANCE ACTIVITY IN THE RUSSIAN FEDERATION AND ABROAD. ISJ Theoretical \& Applied Science 07 (27): 110-117.

Soi: http://s-o-i.org/1.1/TAS-07-27-19 Doi: crossef http://dx.doi.org/10.15863/TAS.2015.07.27.19

\section{НОРМАТИВНО-ПРАВОВОЕ РЕГУЛИРОВАНИЕ СТРАХОВОЙ ДЕЯТЕЛЬНОСТИ В РОССИЙСКОЙ ФЕДЕРАЦИИ И ЗА РУБЕЖОМ}

Аннотация: В статье представлены результаты анализа нормативно-правового регулирования страховой деятельности в Российской Федерации (с учетом действующих федеральных законов, постановлений и распоряжений правительства, НПА Министерств и Банка России и др.), а также страхового законодательства за рубежом (в Болгарии, Франции, Германии, Японии, США и др.), в т.ч. $в$ историческом контексте.

Ключевые слова: страхование, страховой кодекс, кодификация страхового законодательства, кодификация, страховое законодательство, страхование гражданской ответственности, страховая зашита, зарубежный опыт.

Рынок страховых услуг в Российской Федерации на современном этапе развития является быстрорастущим, а также характеризуется стремительностью своего развития. Следует отметить, что постоянно возрастают роль, значение и востребованность страховых услуг в Российской Федерации. Так Побережная И.Ю., Назаренко В.В. подчеркивают, что «регулирование данной области экономики достаточно сложно и многоступенчато» [23, c.243]

В свою очередь, по мнению Симоновой И.В. «развитие страхового рынка как системы страховых и организационно-страховых отношений осуществляется по мере углубления общественного разделения труда, развития финансового рынка, притока на рынок все большего количества страховых субъектов и появления новых видов страховых услуг [27, c.218].

Нормативно-правовая база, регулирующая страховые отношения в Российской Федерации, достаточно объёмная, включающая кодексы, федеральные законы, постановления и распоряжения Правительства Российской Федерации, НПА Министерства финансов, Министерства экономического развития, Банка России, а также приказы (ранее функционировавших) Службы Банка России по финансовым рынкам и Федеральной службы по финансовым рынкам.

Структура законодательства Российской Федерации в области страхования представлена на рисунке 1. 


\begin{tabular}{|c|c|c|c|c|c|}
\hline Impact Factor: & $\begin{array}{l}\text { ISRA (India) } \\
\text { ISI (Dubai, UAF } \\
\text { GIF (Australia) } \\
\text { JIF }\end{array}$ & $\begin{array}{l}=1.344 \\
=0.829 \\
=0.356 \\
=1.500\end{array}$ & $\begin{array}{l}\text { SIS (USA) = } \\
\text { PUHЦ (Russia) } \\
\text { ESJI (KZ) = } \\
\text { SJIF (Morocco) }\end{array}$ & $\begin{array}{l}=0.912 \\
=0.179 \\
=1.042 \\
=2.031\end{array}$ & ICV $($ Poland $) \quad=6.630$ \\
\hline
\end{tabular}
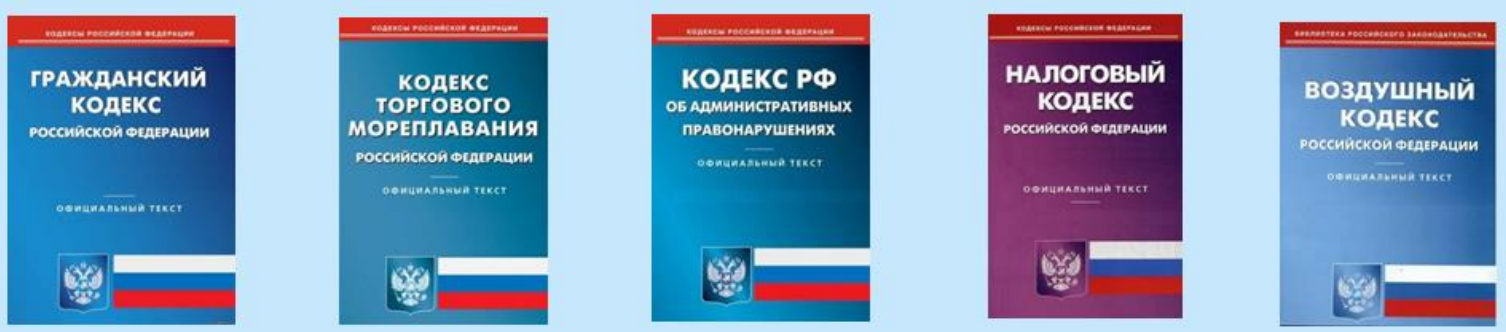

ФЕДЕРАЛЬНЫЕ ЗАКОНЫ

ПОСТАНОВЛЕНИЯ И РАСПОРЯЖЕНИЯ ПРАВИТЕЛЬСТВА РФ

\section{ПРИКАЗЫ}
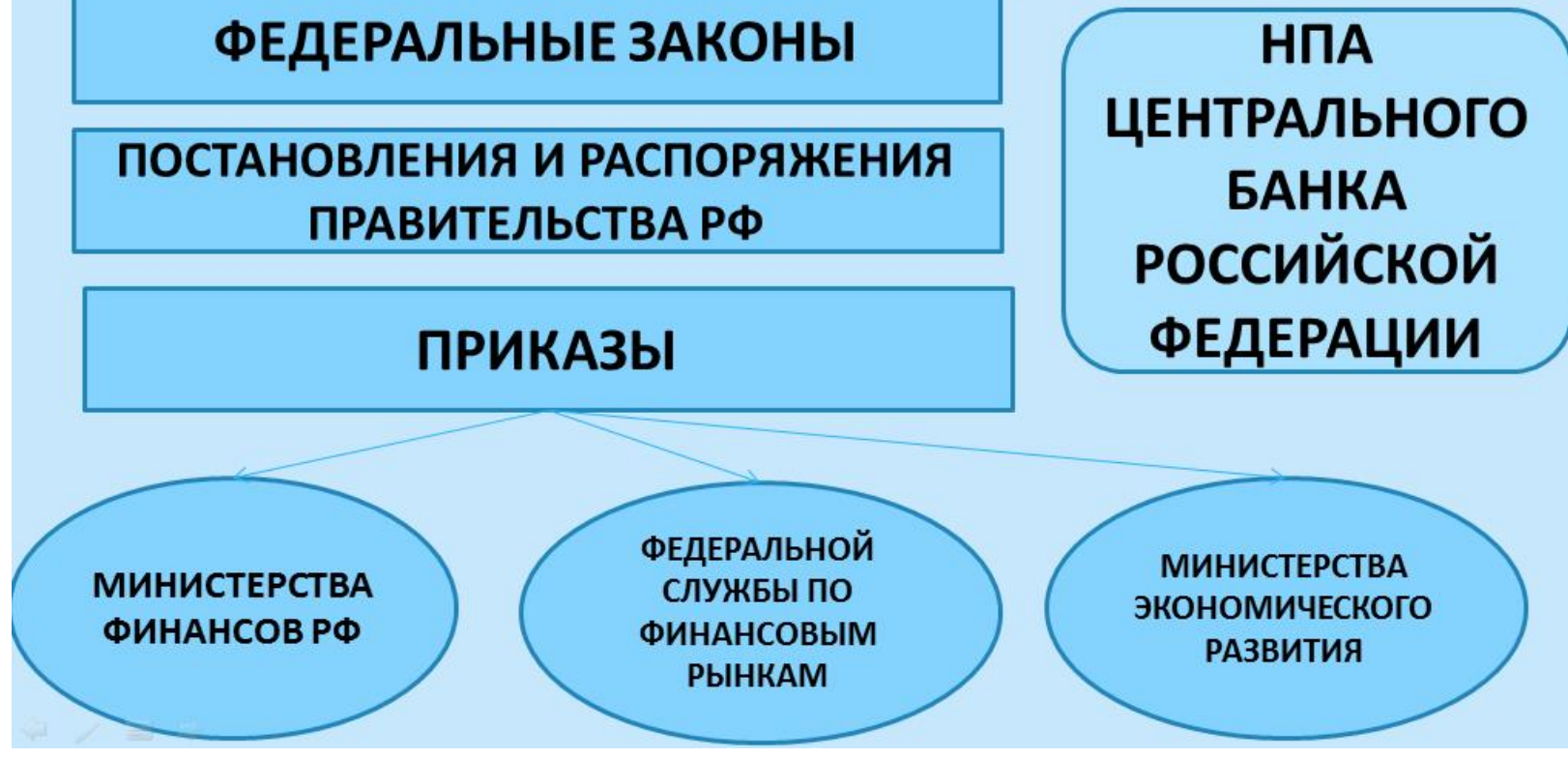

Рисунок 1 - Страховое законодательство в Российской Федерации.

Так, глава 48 Гражданского кодекса Российской Федерации [2] «Страхование» регулирует добровольное (статья 927) и обязательное (статьи 927, 935, 936, 937) страхование; устанавливает право страховщика на оценку страхового риска (статья 945) и перечень интересов, страхование которых не допускается (статья 928); указывает форму договора страхования и последствия её несоблюдения (статья 940); определяет основные положения страхования имущества (статья 930) и ответственности (статья 931, 932,933); закрепляет существенные условия договора страхования (статья 942), начало его действия (статья 957) и возможность досрочного прекращения (статья 958), особенности заключения договоров имущественного (статья 929) и личного (статья 934) страхования.

Кроме того, в этой главе определены сведения, которые необходимо предоставлять страхователю при заключении договора страхования (статья 944); раскрыты сущность и порядок осуществления обязательного государственного страхования (статья 969), перечислены особенности неполного (статья 949) и дополнительного имущественного страхования (статья 950), последствия страхования сверх страховой стоимости (статья 951), а также возможности имущественного страхования от разных страховых рисков (статья 952); описан переход к страховщику прав страхователя на возмещение ущерба (Статья 965); представлены последствия наступления страхового случая по вине страхователя, выгодоприобретателя или застрахованного лица (Статья 963) и основания освобождения страховщика от выплаты страхового возмещения и страховой суммы (Статья 964); указаны сроки исковой давности по требованиям, связанным с имущественным страхованием (Статья 966); предусмотрена возможность и перечислены некоторые особенности перестрахования (статья 967); представлен порядок применения общих правил о страховании к специальным видам страхования (статья 970).

В связи с этим следует согласится с Дырдовым В.И., который считает, что «глава 48 Гражданского кодекса Российской Федерации определяет основные константы процесса страхования» [19, с.276].

В свою очередь, в законе РФ «Об организации страхового дела в Российской Федерации» от 27 ноября 1992 года (с последующими изменениями и дополнениями) 
[5] представлены цели и задачи организации страхового дела (статья 3), объекты страхования (статья 4); обозначены участники страховых отношений (статья 4.1); предусмотрены возможности объединения субъектов страхового дела (статьи 14 и 14.1) и надзора за их деятельностью (глава 4), а также сформулированы вопросы обеспечения финансовой устойчивости и платежеспособности страховщиков (глава 3).

В пункте 1 статьи 32.9 Закона РФ «Об организации страхового дела в Российской Федерации» перечислены виды страхования. Так, в подпунктах 14-21 указаны виды страхования гражданской ответственности. На рисунке 2 они представлены в наглядном виде.

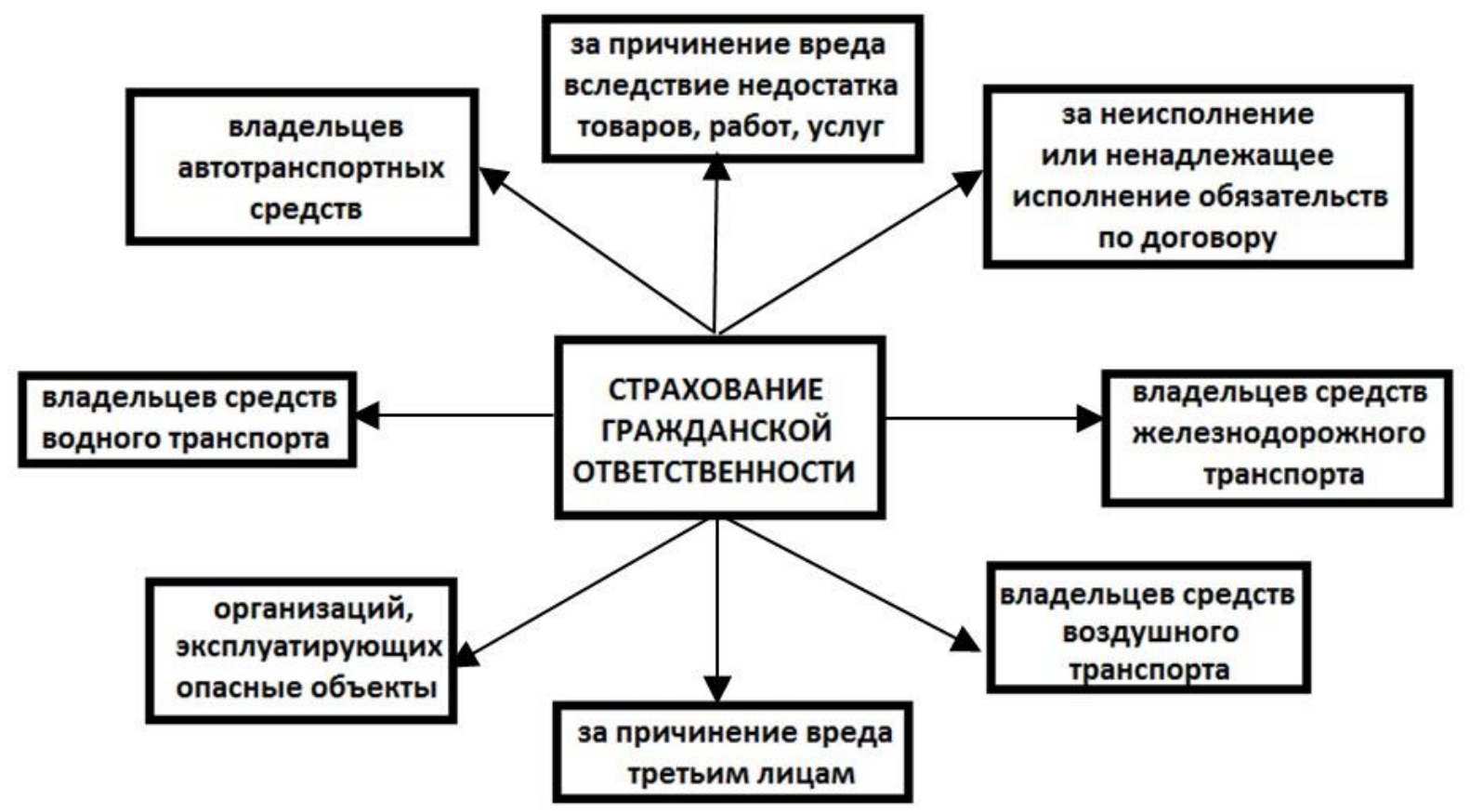

Рисунок 2 - Виды страхования гражданской ответственности.

(согласно пा.14-21 п. 1 ст. 32.9 Закона РФ «Об организации страхового дела в Российской Федерации»)

\begin{abstract}
Следует отметить, что страховые правоотношения между страхователями, страховщиками и выгодоприобретателями гражданские правоотношения, подчиняющиеся гражданскому законодательству. При обнаружении расхождений и неточностей между гражданско - правовыми нормами, содержащимися в Законе о страховании или любых иных актах, и нормами Гражданского кодекса следует руководствоваться последними в силу их приоритета, который установлен п. 2 ст. 3 Гражданского кодекса Российской Федерации [1].
\end{abstract}

Нормы права, регулирующие вопросы страхования закреплены также в статьях 60, $203.3,218,240,301,323,324,324.1,334,335$, $335.1,336.6,336.7,336.8,354,372,375,418$ и главе XV (статьи 246-283) Кодекса торгового мореплавания Российской Федерации [4], где представлен перечень объектов морского страхования, приводятся определение и форма договора морского страхования; указаны случаи освобождения страховщика от ответственности при страховании фрахта, груза, судна, при ядерном взрыве или радиоактивном заражении, а также иные вопросы, относящиеся к морскому страхованию.

В статьях 79,131, 132,133, 134, 135 Воздушного кодекса Российской Федерации [3] представлены нормы права, регулирующие различные виды обязательного страхования (ответственности владельца воздушного судна перед третьими лицами; жизни и здоровья членов экипажа воздушного судна; гражданской ответственности перевозчика перед пассажиром воздушного судна; ответственности перевозчика перед грузовладельцем или грузоотправителем; ответственности эксплуатанта при авиационных работах).

В федеральном законе от 25.04.2002 N 40Ф3 «Об обязательном страховании гражданской ответственности владельцев транспортных средств» [7] представлены основные термины, понятия и принципы обязательного страхования, условия и порядок его осуществления, порядок компенсационных выплат, их максимальные размеры; требования к страховщикам, особенности осуществления ими страховых 
операций, а также функции, полномочия и имущество профессиональных объединений страховщиков и другие вопросы.

В постановлении Правительства Российской Федерации от 07.05.2003 N 263 "Об утверждении Правил обязательного страхования гражданской ответственности владельцев транспортных средств" [11] представлены соответствующий понятийный аппарат и объект обязательного страхования; установлены срок действия, порядок заключения, изменения, продления и досрочного прекращения договора обязательного страхования; описаны действия лиц при наступления страхового случая; закреплены порядки определения размера страховой выплаты при причинении вреда жизни и здоровью потерпевших и размера подлежащих возмещению убытков при причинении вреда имуществу потерпевшего; перечислены случаи, при которых страховщик имеет право предъявлять регрессные требования.

Приказ Минэкономразвития России от 22.08.2011 N 409 "Об утверждении программ подготовки арбитражных управляющих в делах о банкротстве финансовых организаций" [15] утверждает программы подготовки арбитражных управляющих в делах о банкротстве страховых организаций.

Приказ Минфина России от 02.07.2012 № 101н «Об утверждении Требований, предъявляемых к составу и структуре активов, принимаемых для покрытия собственных средств страховщика» [14] содержит общие положения; виды активов, принимаемые и не принимаемые для покрытия собственных средств страховщика; а также требования к структуре принимаемых активов.

В приказе Федеральной службе по финансовым рынкам от 24 мая 2012 года № 1233/п3-н [16] утверждены формы статистической отчетности, основные ее показатели, детально описан порядок ее составления (в разрезе каждого раздела, графы и строки) и представления.

Распоряжением Правительства РФ от 25.09 .2002 N 1361-p [13] была утверждена Концепция развития страхования в Российской Федерации, в которой представлена оценка состоянию страхового дела, определены основные цели, задачи и направления развития страхования в Российской Федерации. Следует отметить, что один из блоков концепции посвящен совершенствованию страхового законодательства в нашем государстве.

Впоследствии

поручением Правительства Российской Федерации от 18 ноября 2008 г. ВП-П13-6891 была одобрена Стратегия развития страховой деятельности в Российской Федерации на среднесрочную перспективу, основные итоги реализации которой подведены в новой стратегии - Стратегии развития страхового рынка в Российской Федерации до 2020 года (утвержденной распоряжением Правительства Российской Федерации от 22 июля 2013 года №1293-р). Так, в частности, была улучшена страховая защита участников, которые возникают в сфере пассажирских перевозок, производится реформирование системы обязательного медицинского страхования, улучшены меры государственных поддержки в сфере сельскохозяйственного страхования, увеличены требования к страховщикам, введено обязательное страхование гражданской ответственности владельца опасного объекта за причинение вреда в результате аварии на опасном объекте, совершенствование условий осуществления обязательного страхования гражданской ответственности владельцев транспортных средств, совершенствуется правовое регулирование деятельности страховых актуариев. В этом контексте следует отметить, что в 2013 году был принят закон «Об актуарной деятельности в Российской Федерации» [10], который вступает в силу с 1 января 2015 года (за исключением статьи 17).

В законе приводятся правовое регулирование актуарной деятельности (статья 1), основания ее осуществления (статья 4), основные термины и понятия (статья 2), требования к актуарному заключению (статья 5), права и обязанности субъекта и заказчика актуарной деятельности (статья 6), полномочия уполномоченного органа (статья 8), стандарты актуарной деятельности (статья 10). Отдельное место в законе уделено саморегулируемым организациям актуариев, их функциям, правам и обязанностям, вопросам надзора за их деятельностью (статьи 11-15).

Статьи закона также посвящены обязательному актуарному оцениванию, требованиям к актуариям и ответственным актуариям, обеспечению имущественной ответственности при осуществлении актуарной деятельности.

Цель Стратегии развития страховой деятельности в Российской Федерации на период до 2020 года заключается в комплексном содействии развитию страховой отрасли, а также превращению её в стратегически значимый сектор российской экономики. Для достижения поставленной цели необходимо решить задачи, связанные с созданием условий, способствующих развитию, прежде всего, добровольных видов страхования и взаимного страхования; формированием добросовестной конкуренции и новых подходов в страховой деятельности, направленных на повышение качества 
предоставляемых страховым услуг и значимости страховой защиты, увеличение эффективности страховой деятельности, а также удовлетворение массовой потребности в страховых услугах. При этом отмечается важность сокращения количества причин для споров между страховщиками и потребителями страховых услуг и необходимость создания эффективных механизмов досудебного урегулирования споров (путем возможного создания института страхового омбудсмена). Среди условий, способствующих достижению поставленной цели и решению задач, отмечаются такие как увеличение уровня социально-экономического развития страны, эффективное нормативноправовое регулирование страховой деятельности, повышение социальной ответственности бизнеса, а также совершенствование государственного страхового надзора, судебной системы и системы исполнения судебных решений, становление международного финансового центра в Российской Федерации.

Согласно «дорожной карте» Стратегии развития страховой деятельности в Российской Федерации до 2020 года планируется увеличение объема совокупной страховой премии, её доли в ВВП и на душу населения, доли страхования жизни и добровольных видов в совокупном объёме премий, а также снижение доли обязательных видов страхования. В намеченном плане мероприятий обозначены следующие: совершенствование регулирования обязательного и стимулирование развития добровольного страхования, расширение сферы деятельности субъектов страхового дела, развития инфраструктуры рынка страхования, защита прав потребителей услуг страхования, а также увеличение страховой культуры, повышение популярности страхования.

Следует также отметить, что вопросы страхования находят отражения и в Посланиях Президента Федеральному Собранию. Так, например, в последнем, Владимир Путин особое внимание уделил медицинскому страхованию [37].

Наиболее оптимальным решением существующих проблем является принятие Страхового Кодекса Российской Федерации, представляющего собой единый нормативноправовой акт, всесторонне регулирующий страховые отношения.

Говоря о кодификации российского законодательства необходимо подчеркнуть накопленный исторический опыт. Так, работа по кодификации российского законодательства была начата еще во время правления Екатерины Второй. Однако, наиболее часто эту сложную и трудоемкую работу связывают, прежде всего, с деятельностью Михаила Михайловича
Сперанского, который в первой половине 19 века осуществил масштабную кодификацию российского законодательства.

Процесс кодификации активно продолжается и в современной России. К данному моменту уже приняты Бюджетный, Налоговый, Гражданский, Таможенный, Уголовный, Трудовой, Жилищный, Воздушный, Земельный, Семейный, Градостроительный и другие кодексы. Благодаря их введению удалось не только упростить законодательство в соответствующей отрасли права, сделать его более понятным и менее противоречивым, но и улучшить положение физических и юридических лиц. При этом уменьшилось и количество совершаемых правонарушений.

Как известно, родиной страхового права является европейское государство Испания, в котором еще в 15 веке появился специальный кодекс Los Capitolos de Barcelona (1435 г.). В нем предусматривались и факторы, образующие страховой случай, и порядок проверки, и, что немаловажно, порядок осуществления страховых выплат.

Позднее, уже в 18 веке страховые кодексы появились и в Германии. Однако, в настоящее время в качестве источников страхового права выступает ряд законов, некоторые из них приняты были более 100 лет назад [38].

Так, в частности, во Франции ключевое место в страховом праве занимает именно Страховой кодекс Франции (Code des Assurances), введенный в действие более 35 лет назад (декретами № 76-666 и 76-667 и решением министра экономики и финансов от 16 июля 1976 года. Он представляет собой сборник законов и нормативно-правовых актов в области страхования, в которые по мере необходимости вносятся соответствующие изменения.

Так, Страховой кодекс Франции включает законодательную часть и нормативные положения. В составе законодательной части пять томов (договор страхования, обязательное страхование, компании (страховщики), личное страхование, страховые агенты). В составе нормативных положений выделяются те же самые пять томов, которые дополняют законодательную часть. Так, в частности, в нормативных положениях приводятся обязанности страховщика и страхователя, общие правила страхования по каждому виду страхования, понятия полиса медицинского страхования, страхового сертификата, франшизы, штрафов и других понятий, а также нормы права, регулирующие деятельность страховых групп).

Следует отметить, что благодаря введению Страхового кодекса во Франции произошла существенная эволюция форм, размеров и стратегий французских страховых компаний. 
Нельзя не сказать, что французская страховая группа АХА стала одним из лидеров мирового страхового рынка.

В Японии также принят Национальный Страховой кодекс, который представляет собой комплекс нормативно-правовых норм, всесторонне регулирующих страховые отношения в государстве.

В Соединенных штатах Америки, которые являются лидером на мировом рынке страхования, существует особое законодательное регулирование страховой деятельности: отсутствует единый нормативно-правовой акт на федеральном уровне. Каждый штат имеет свое страховое законодательство, требования к страховых брокерам и страховым компаниям. Следует отметить, что в некоторых субъектах (штатах) США приняты именно Страховые Кодексы, в которые помимо норм права включены еще и судебные решения в области страхового права, что позволяет при чтении кодекса знакомиться и с накопленной в стране судебной практикой по вопросам страхования.

В Болгарии с 1999 года действует Кодекс социального страхования, регулирующий отношения в области государственного и дополнительного социального и пенсионного страхования [36]. Он включает в себя три части, а именно:

1) государственное общественное страхование (состоит из девяти глав, в которых изложены общие положения, порядок возмещения при временной нетрудоспособности и трудоустройстве, денежных возмещений при безработице, вопросы страхования от несчастного случая на производстве и профессионального заболевания, правила обязательного пенсионного страхования и др.);

2) дополнительное социальное страхование (состоит из тридцати одной главы, посвященных вопросам дополнительного обязательного пенсионного страхования, налоговым облегчениям, правам застрахованных лиц, вопросам бухгалтерского учета и отчетности и др.);

3) принудительные административные меры и административная ответственность (состоит из трех глав, посвященных вопросам, обозначенным в названии части, а также заключительных положений).

Следует отметить, что каждая часть разделена на главы (которые, в свою очередь, детализированы на разделы).

Во второй части главы объединены в 5 долей. Первая доля посвящена обществам дополнительного социального страхования (состоит из 1 главы, детализированной на три раздела, вторая - дополнительному обязательному пенсионному страхованию (состоит из 11 глав, последняя имеет два раздела), третья - дополнительному добровольному пенсионному страхованию (состоит из 9 глав), четвертая - дополнительному добровольному страхованию от безработицы (состоит из 9 глав, одна из которых (посвященная правам застрахованных лиц и страховщиков) детализирована на три раздела, пятая преобразованиям, прекращению и несостоятельности обществ и фондов дополнительного социального страхования (включает одну главу).

О назревшей необходимости введения кодекса о страховании говорили несколько лет назад и в Беларуси [35], где законодательство в сфере страхования не представлено в виде единого законодательного акта. О введении страхового кодекса задумывались и в соседней Украине, причем достаточно давно. В 2006 году в Азербайджане председатель постоянной комиссии по экономической политики парламента Зияд Самедзаде выступил с предложением ввести Страховой кодекс в стране. При этом он отметил, что в результате мониторинга «было выявлено множество пробелов и существующих на страховом рынке проблем. С целью развития данного сегмента рынка и решения проблем мы выступили с предложением о подготовке Страхового кодекса» [34].

Однако, ни в Украине, ни в Беларуси, ни в Азербайджане страховые кодексы до настоящего времени не приняты.

Особого внимания заслуживает факт того, что о создании и последующем введении Страхового Кодекса говорили в России. Еще в апреле 2000 года на заседании Общественного экспертного совета по страховому законодательству при Аналитическом управлении Совета Федерации поднимался вопрос о необходимости систематизации всех имеющихся источников страхового права. Отмечалось, что это должно стать первым этапом в пути к принятию Страхового кодекса. Планируемое время было отмечено - 1-1,2 года. Однако, уже прошло 15 лет, а проблема так и не решена.

Таким образом, следует сделать вывод о том, что нормативно- правовое регулирование в Российской Федерации множеством актов, а также закреплено в стратегиях и Посланиях Президента Российской Федерации. Однако, в целях стимулирования роста заинтересованности россиян к страховой защите, повышение страховой культуры жителей нашего государства, a также решения ряда других проблем, необходимо принятие единого комплексного документа в сфере страхования в виде Страхового кодекса Российской Федерации. 


\section{References:}

1. (2015) Grazhdanskij kodeks Rossijskoj Federacii (chast' pervaja) ot 30.11.1994 N 51FZ (red. ot 13.07.2015).

2. (2015) Grazhdanskij kodeks Rossijskoj Federacii (chast' vtoraja) ot 26.01.1996 N 14FZ (red. ot 29.06.2015).

3. (2015) Vozdushnyj kodeks Rossijskoj Federacii ot 19.03.1997 N 60-FZ (red. ot 13.07.2015).

4. (2015) Kodeks torgovogo moreplavanija ot 30.04.1999 № 81-FZ (red. ot 13.07.2015).

5. (2015) Zakon RF ot 27.11.1992 N 4015-1 (red. ot 29.06.2015) «Ob organizacii strahovogo dela v Rossijskoj Federacii».

6. (2014) Federal'nyj zakon ot 27.07.2010 N 225FZ (red. ot 04.11.2014) «Ob objazatel'nom strahovanii grazhdanskoj otvetstvennosti vladel'ca opasnogo ob\#ekta za prichinenie vreda $v$ rezul'tate avarii na opasnom ob\#ekte».

7. (2014) Federal'nyj zakon ot 25.04.2002 N 40FZ (red. ot 04.11.2014) «Ob objazatel'nom strahovanii grazhdanskoj otvetstvennosti vladel'cev transportnyh sredstv».

8. (2014) Federal'nyj zakon ot 14.06.2012 N 67FZ (red. ot 04.11.2014) «Ob objazatel'nom strahovanii grazhdanskoj otvetstvennosti perevozchika za prichinenie vreda zhizni, zdorov'ju, imushhestvu passazhirov i o porjadke vozmeshhenija takogo vreda, prichinennogo pri perevozkah passazhirov metropolitenom».

9. (2012) Federal'nyj zakon ot 24.11.1996 N 132FZ (red. ot 03.05.2012) «Ob osnovah turistskoj dejatel'nosti v Rossijskoj Federacii».

10. (2015) Federal'nyj zakon ot 02.11.2013 N 293FZ (red. ot 08.03.2015) «Ob aktuarnoj dejatel'nosti v Rossijskoj Federacii».

11. (2015) Postanovlenie Pravitel'stva Rossijskoj Federacii ot $14.09 .2005 \mathrm{~N} 567$ (red. ot 02.06.2015) «Ob obmene informaciej pri osushhestvlenii objazatel'nogo strahovanija grazhdanskoj otvetstvennosti vladel'cev transportnyh sredstv».

12. (2013) Strategija razvitija strahovogo rynka v Rossijskoj Federacii do 2020 goda (odobrena rasporjazheniem Pravitel'stva Rossijskoj Federacii ot 22 ijulja 2013 goda №1293-r)

13. (2002) Koncepcija razvitija strahovanija v Rossijskoj Federacii (utv. rasporjazheniem Pravitel'stva RF ot 25.09.2002 N 1361-r).

14. (2012) Prikaz Minfina Rossii ot 02.07.2012 № 100n (red. ot 29.10.2012) «Ob utverzhdenii Porjadka razmeshhenija strahovshhikami sredstv strahovyh rezervov» .

15. (2012) Prikaz Minjekonomrazvitija Rossii ot 22.08.2011 (red. ot 13.04.2012) N 409 "Ob utverzhdenii programm podgotovki arbitrazhnyh upravljajushhih $\mathrm{v}$ delah $\mathrm{O}$ bankrotstve finansovyh organizacij".

16. (2012) Prikaz FSFR Rossii ot 24.05.2012 № 12-33/pz-n «Ob utverzhdenii Formy statisticheskoj otchetnosti № 1-S «Svedenija ob osnovnyh pokazateljah dejatel'nosti strahovshhika» i Porjadka ee sostavlenija i predstavlenija».

17. Susljakova ON (2011) Strahovanie. Uchebnoe posobie. Kaluga, Izdatel'stvo «Vash dom\#», 2011. 2-e izd., pererab. i dop., 220 p.

18. Groshev IV, Jur'ev VM (2005) Psihologija jekonomicheskih otnoshenij // Obshhestvo i jekonomika. 2005. №6. pp. 123-144.

19. Dyrdov VI (2012) Strahovanie kak jelement sistemy upravlenija imushhestvennymi riskami. Biznes. Obrazovanie. Pravo. Vestnik Volgogradskogo instituta biznesa. 2012. № 3. pp. 276-278.

20. Kuzina LA (2013) Organizacionnojekonomicheskij mehanizm stimulirovanija innovacij $\mathrm{V}$ pishhevoj promyshlennosti. Predprinimatel'stvo. - 2013. - №7. - pp. 133142.

21. Mamontov VD (2007) Nekotorye razmyshlenija o sostojanii otechestvennoj jekonomicheskoj nauki. Social'no-jekonomicheskie javlenija i processy. 2007. № 1 (5). pp. 78-83.

22. Nosov VV, Usanov AJ, Kotar OK (2013) Zakon ob agrostrahovanii: novye podhody $\mathrm{i}$ novye problemy. Nacional'nye interesy: prioritety i bezopasnost'. 2013. № 18. pp. 2-8.

23. Poberezhnaja IJ, Nazarenko VV (2015) Istoricheskij aspekt razvitija strahovanija $\mathrm{V}$ Rossii. Biznes. Obrazovanie. Pravo. Vestnik Volgogradskogo instituta biznesa. 2015. № 1 (30). pp. 241-244.

24. Rodionova NK, Burmistrova AA, Kondrashova IS (2012) Resursy modernizacii jekonomiki Rossii: social'no-demograficheskij aspekt. Social'no-jekonomicheskie javlenija i processy. 2012. № 5-6 (39-40). pp. 106-111

25. Sajapin AV, Kozhevnikova TM (2013) Strukturnaja modernizacija kak faktor konkurentosposobnosti predprijatij APK. Social'no-jekonomicheskie javlenija i processy. 2013. № 2 (48). pp. 102-109.

26. Sergienko NS, Susljakova ON (2015) Gosudarstvennoe strahovanie v pervoj polovine XX veka. Audit i finansovyj analiz. 2015. № 3. pp. 406-410.

27. Simonova IV (2013) Teoretikometodologicheskie podhody $\mathrm{k}$ analizu strahovogo rynka. Biznes. Obrazovanie. Pravo. 


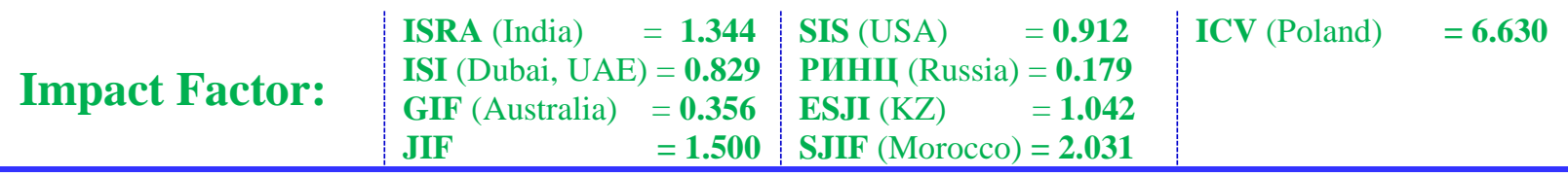

Vestnik Volgogradskogo instituta biznesa. 2013. № 2 (23). pp. 217-220.

28. Spletuhov JA, Djuzhikov EF (2014) Harakteristiki strahovyh rynkov stran - chlenov Edinogo jekonomicheskogo prostranstva. Finansovaja analitika: problemy i reshenija. 2014. № 22. pp. 26-34.

29. Susljakova ON (2013) Osobennosti razvitija sovremennogo strahovogo rynka Rossii. Aktual'nye problemy social'nojekonomicheskih issledovanij. Sbornik Sbornik 4-j Mezhdunarodnoj nauchno-prakticheskoj konferencii, 2013. pp. 71-78.

30. Susljakova ON (2015) Strahovanie kak neot\#emlemyj jelement social'nojekonomicheskogo razvitija obshhestva. Sovremennye issledovanija social'nyh problem. 2015. № 1 (21). pp. 270-274.

31. Chernova GV, Kalajda SA (2014) Vneshnie faktory razvitija sovremennogo rossijskogo strahovogo rynka. Finansy i kredit. 2014. № 2 (578). pp. 30-39.

32. Shmeleva LA (2014) Instrumenty podderzhki innovacionnoj dejatel'nosti promyshlennyh predprijatij v sovremennoj Rossii. Upravlenie jekonomicheskimi sistemami: jelektronnyj nauchnyj zhurnal. - 2014. - №12(72). - pp.33.

33. Shor IM (2013) Trebovanija k investicionnoj politike strahovyh kompanij s pozicii gosudarstva. Regional'naja jekonomika: teorija i praktika. 2013. № 41. pp. 43-46.

34. (2015) V Azerbajdzhane mozhet byt' prinjat Strahovoj kodeks. Available: http://news.day.az/economy/51218.html (Accessed: 20.07.2015).

35. (2015) V Belarusi razrabatyvajut Strahovoj kodeks.

Available: http://www.giport.ru/news/7807/ (Accessed: 20.07.2015).

36. (2015) Kodeks social'nogo strahovanija Bolgarii. Available: http://www.onlinebg.ru/mediawiki/index.php/K ODEKS SOCIAL"NOGO_STRAHOVANIJa, BOLGARIJa (Accessed: 20.07.2015).

37. (2015) Poslanie Prezidenta Federal'nomu Sobraniju Available: http://www.kremlin.ru/events/president/news/4 7173 (Accessed: 20.07.2015).

38. (2015) Strahovoe pravo. Available: http://www.ido.rudn.ru/lectures/213/P2.html (Accessed: 20.07.2015). 